\title{
Review
}

Journal of

Molecular Microbiology

and Biotechnology
J Mol Microbiol Biotechnol 2007;13:1-11

DOI: $\underline{10.1159 / 000103591}$

\section{The Energy Spilling Reactions of Bacteria and Other Organisms}

\author{
James B. Russell \\ US Plant, Soil and Nutrition Laboratory, Agricultural Research Service, USDA, Ithaca, N.Y., USA
}

\section{Key Words \\ Energy spilling • Uncoupling • Growth yield • Futile cycles}

\section{Abstract}

For many years it was assumed that living organisms always utilized ATP in a highly efficient manner, but simple growth studies with bacteria indicated that the efficiency of biomass production was often at least 3-fold lower than the amount that would be predicted from standard biosynthetic pathways. The utilization of energy for maintenance could only explain a small portion of this discrepancy particularly when the growth rate was high. These ideas and thermodynamic arguments indicated that cells might have another avenue of energy utilization. This phenomenon has also been called 'uncoupling', 'spillage' and 'overflow metabolism', but 'energy spilling' is probably the most descriptive term. It appears that many bacteria spill energy, and the few that do not can be killed (large and often rapid decrease in viability), if the growth medium is nitrogen-limited and the energy source is in 'excess'. The lactic acid bacterium, Streptococcus bovis, is an ideal bacterium for the study of energy spilling. Because it only uses substrate level phosphorylation to generate ATP, ATP generation can be calculated with a high degree of certainty. It does not store glucose as glycogen, and its cell membrane can be easily accessed. Comparative analysis of heat production, membrane voltage, ATP production and Ohm's law indicated that the energy spilling reaction of S. bovis is mediated by a futile cycle of protons through the cell membrane. Less is known about Escherichia coli, but in this bacterium energy spilling could be mediated by a futile cycle of potassium or ammonium ions. Energy spilling is not restricted to prokaryotes and appears to occur in yeasts and in higher organisms. In man, energy spilling may be related to cancer, ageing, ischemia and cardiac failure.

Copyright $\odot 2007$ S. Karger AG, Basel

\section{Introduction}

More than 30 years ago, Lehninger's [1975] textbook Biochemistry had the phrase 'cells are capable of regulating their metabolic reactions and biosynthesis to achieve maximum efficiency and economy'. Later versions stated [Lehninger et al., 1993] that 'cells have evolved highly efficient mechanisms for capturing the energy of sunlight, or extracting this energy of oxidized fuels, and coupling thus obtained energy to the many energy consuming processes of the cell'. Both editions mentioned the brown adipose, a tissue in newborns mammals that functions in an 'uncoupled' fashion to produce heat and keep them warm, but this example is presented more as an artifact of biology rather than a fundamental principle or strategy.

To many scientists the idea that living organisms might deliberately dissipate or 'spill' ATP sounds better suited to a late night television 'infomercial' and drugs that cause miraculous body weight loss rather than a serious scientific discussion. However, Russell and Cook [1995] concluded that many bacteria have reactions that dissi-

\section{KARGER \\ Fax +4161306 1234 \\ E-Mail karger@karger.ch}

www.karger.com (c) 2007 S. Karger AG, Basel

$1464-1801 / 07 / 0133-0001 \$ 23.50 / 0$

Accessible online at:

www.karger.com $/ \mathrm{mmb}$
J.B. Russell

US Plant, Soil and Nutrition Laboratory

Tower Road

Ithaca, NY 14853 (USA)

Tel. +1 607255 4508, Fax +1 607255 3904, E-Mail jbr8@cornell.edu 


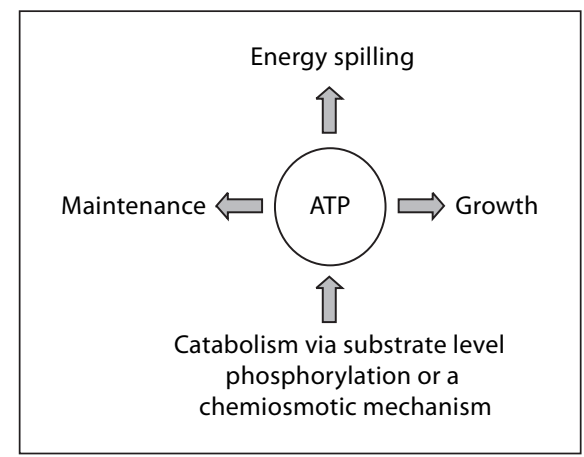

Fig. 1. Production and utilization of ATP.

pate excess ATP when the catabolic rate is faster than the anabolic rate. This short review is not designed to re-iterate all of the evidence presented in this earlier manuscript. However, the idea that bacteria can spill energy has been strengthened by additional experiments and a more precise delineation of the mechanism in Streptococcus bovis. The term 'energy spilling' will be used to describe nongrowth dissipation of excess ATP, but the reader should realize that this phenomenon has also been called 'uncoupling', 'spillage' and 'overflow metabolism' (fig. 1).

\section{ATP and Growth}

In its most basic sense, biological growth is a complicated set of reactions that couples the exergonic reactions of catabolic schemes with the endergonic anabolic pathways of monomer biosyntheses and polymerization [Repke, 2004]. This coupling of exergonic and endergonic reactions is typically mediated by ATP. The importance of ATP as an 'energy rich' intermediate in this process was first fully appreciated by Lipmann [1941], but as Nichols [1982] more recently noted, 'It is frequently, and misleadingly, supposed that the phosphate anhydride bonds of ATP are "high energy" bonds which are capable of storing and driving reactions in otherwise unfavorable directions. However, it should be clear that it is the extent to which the observed mass-action ratio is displaced from equilibrium which defines the capacity of the reactants to do work, rather than the attribute of a single component.' This re-definition of bioenergetics as chemical equilibria greatly clarified the once diverse concepts of catabolism and anabolism, but this clarification did not negate the fact that biological systems have evolved to use reactions involving ATP rather than other molecules.

\section{Yield of ATP or $\mathbf{Y}_{\text {ATP }}$}

Bauchop and Elsden [1960] performed some simple growth experiments with anaerobic bacteria that had known pathways of ATP production and reported that the bacterial growth efficiency (yield or $\mathrm{Y}_{\text {ATP }}$ ) was $10.5 \mathrm{~g}$ cells per mole of ATP. The 10.5 value was actually a ratio derived from a range of 8.3-12.6, but inherent variation was largely ignored, and at least one textbook of microbiology still treats the $10.5 \mathrm{~g}$ cells per mole of ATP as a biological constant [Brock and Madigan, 1991]. In some cases, $\mathrm{Y}_{\text {ATP }}$ has even been used as a basis for predicting the amount of ATP that a bacterium is able to generate from its catabolic scheme. However, the assumption that $\mathrm{Y}_{\mathrm{ATP}}$ is a constant was soon to be questioned; there was a very active interest in bacterial bioenergetics, and the question arose: Why could $\mathrm{Y}_{\mathrm{ATP}}$ values vary as much as 10 -fold [Tempest, 1978; Stouthamer, 1979]?

\section{Methods of Generating ATP}

One explanation for the discrepancies in $\mathrm{Y}_{\mathrm{ATP}}$ was simply the inaccuracy of microbiologists to estimate the amount of ATP generated by catabolic pathways. Indeed, this was and continues to be a problem. Otto Warburg proposed that inorganic phosphate could be added to aldehyde groups to create compounds like 1,3-diphosphoglyceric acid, and it soon 'became apparent that reverse reactions of a similar sort could be coupled to ATP formation from ADP and $\mathrm{P}_{\mathrm{i}}^{\prime}$. These mechanisms are known as substrate level phosphorylation, and appear to be stoichiometric. However, substrate level phosphorylation could not explain all of the ATP that was produced by mitochondria or aerobic bacteria.

Much time was devoted to identification of a high-energy intermediate (sometimes called the $\mathrm{X}$ factor), but these efforts were futile. Mitchell [1961] proposed a radical alternative to substrate level phosphorylation. Mitchell reasoned that the movement of ions across an electrochemical membrane potential could provide the energy needed to produce ATP. This theory was confirmed by the discovery of a membrane-bound ATP synthase that could produce ATP [Racker, 1977]. Since this time, a variety of chemiosmotic mechanisms have been discovered, and many are linked to sodium as well as protons [Dimroth, 1987; Skulachev, 1994].

While one cannot deny the fact that oxidative phosphorylation and chemiosmotic mechanisms are the dominant means of generating ATP in aerobes, there has nev- 
er been a firm consensus on the degree of ATP coupling. This point is readily illustrated by a simple example. When Escherichia coli is grown aerobically, the amount of ATP could be more than 9-fold greater than the amount generated from the anaerobic pathway producing acetate, formate and ethanol ( 28 vs. 3 ATP per glucose) [Gottschalk, 1986], but the yield of cells (biomass) is only 2-fold greater [Stouthamer and Bettenhaussen, 1977]. Given this comparison, it seems readily apparent that ATP production can only be reliably estimated if the sole mechanism of ATP generation involves substrate level phosphorylation.

These discrepancies in ATP production from oxidative phosphorylation could be due to either: (1) the failure to move ions, or (2) a less than stoichiometric coupling the ion gradient and ATP synthesis. Cited values typically range from 2 to 4 protons translocated per ATP [Maloney, 1990; Hinkle et al., 1991], but structural studies on the membrane-bound ATPase have given us new information. Based on the ratio of membrane 'c' subunits to cytoplasmic gamma subunits, a stoichiometry of 3.33 of protons per ATP now seems reasonable; however, some organisms can vary this stoichiometry this by altering the number of $\mathrm{c}$ subunits in the ring [Fillingame and Dmitriev, 2002].

Rhodobacter capsulatus uses chromatophores (subbacterial vesicles) and the $\mathrm{F}_{1} \mathrm{~F}_{0}$-ATPase to generate $\Delta \mathrm{p}$ and ATP, and the coupling efficiency is usually very high. However, when Feniouk et al. [2005] energized the chromatophores with a flashing light, the transmembrane voltage and $\mathrm{pH}$ difference 'relaxed'. This latter result indicated that protons were leaking. However, there was no detectable detachment of $\mathrm{F}_{1}$ from $\mathrm{F}_{0}$ and the slip persisted for hours. Because the slip could be reversed at least partially by the addition of ADP or ATP and had no protonmotive force $(\Delta p)$ threshold, the authors concluded that the 'proton slip' was probably caused by 'the freewheeling of the central rotary shaft, subunit $\gamma$, in an open structure of the $(\alpha \beta)^{3}$ hexagon with no nucleotides in the catalytic sites'. Whether this is a common feature physiological of oxidative phosphorylation in other organisms has yet to be determined.

\section{Cell Composition}

Bacteria can vary the composition of their cells, and this point was illustrated by the classic 'shift-up and shiftdown' experiments of Maaloe [Cooper, 1993]. When E. coli was provided with different energy sources, growth
Table 1. ATP needed to synthesize protein, nucleic acid, polysaccharide or lipid (recalculated Stouthamer, 1973)

\begin{tabular}{ll}
\hline Macromolecule & $\begin{array}{l}\text { ATP requirement } \\
\text { mmol/g }\end{array}$ \\
\hline Protein & 36.4 \\
RNA & 15.3 \\
DNA & 18.8 \\
Polysaccharide & 12.6 \\
Lipid & 2.0 \\
\hline
\end{tabular}

rate could be varied nearly 10 -fold. When the cells grew faster (shift-up), there was an increase in ribosomal RNA, and conversely there was a decrease in ribosomal RNA if the cells grew slower (shift-down). Not all bacteria have such a large a range in potential growth rates and vary their ribosomal RNA to as great an extent as E. coli [Russell, 1986], but many bacteria accumulate polysaccharide. This polysaccharide can be an extracellular material that helps protect the cell or intracellular glycogen that is used for energy during periods of starvation. Some aerobes accumulate $\beta$-hydroxybutyrate as an alternative to glycogen.

In the 1970s, Stouthamer [1973] did some simple calculations that were based on standard pathways of biosynthesis. Stouthamer used a cell composition that was typical of laboratory cultures of $E$. coli, but generalizations for all bacteria could be made. Monomers such as amino acids and nucleotides were not very costly to make, but the polymerization of these monomers into macromolecules requires a very large amount of ATP. Protein was the most costly polymer to synthesize, and it accounts for approximately $1 / 2$ of the total ATP requirement, whereas polysaccharide was relatively inexpensive to synthesize (table 1). When the mass of the polymer and the ATP requirement for biosynthesis were compared, it became apparent that the $\mathrm{Y}_{\mathrm{ATP}}$ of bacteria should be $32 \mathrm{~g}$ cells/mole ATP [Stouthamer, 1973], a value 3 times greater than estimated by Bauchop and Elsden [1960].

\section{So Why Is Protein So Expensive to Make?}

This point was addressed by Harold [1986]. The inefficiency of protein synthesis may be related to the information protein contains and the 'willingness' of living organisms to invest a large amount of energy to make sure that the information (sequence) is correct. This principle is supported by a 'thought experiment' called 'Max- 
well's demon'. In 1868, James Maxwell hypothesized a Demon that was able to operate a frictionless door that connected two rooms separated by a partition. Whenever air molecules looked as if they would pass through the opening, the demon opened the door. Afterwards he closed the door to trap the molecule. The demon did this over and over until there was a concentration gradient of air molecules between the two rooms. A concentration gradient is energy. Where did the energy come from? The demon had information when the door should be opened and closed. Hence, energy and information are inter-convertible!

\section{Maintenance Energy}

Stouthamer's calculations [1973] only considered growth-related functions and did not address the fact that bacteria must expend a portion of their ATP to maintain their cells. Bacterial maintenance energy has not been precisely defined, but at least three functions are known to contribute: (1) motility, (2) turnover of macromolecules (e.g. protein) and sensory molecules (e.g. ppGpp and histidine kinases), and (3) re-establishment of ion gradients across the cell membrane. Because membranes have an inherent 'leakiness', the third component is clearly the most important one. Bacterial maintenance is estimated indirectly from growth rate-dependent changes in bacterial yield, and it is possible to compare maintenance to the overhead of a small business. When the rate of cash flow (glucose consumption) is slow, overhead (maintenance) makes a larger proportion of the total budget (total ATP availability). Thus, the contribution of maintenance is more pronounced when fermentation and growth rates are slow.

Maintenance energy is most easily demonstrated in continuous culture [Herbert et al., 1956]. In batch cultures, the bacteria grow as fast as they can; maintenance only makes up a small part of the total ATP consumption, and the composition of the growth medium changes. In continuous culture, steady states are maintained, and cell composition (including enzymes) stabilizes. The principles of continuous culture were developed by Monod [1949] and Novick and Szilard [1950]. Monod was a Frenchman, and he called his device a chemostat. In a chemostat, medium is added to the growth or culture vessel at a constant rate from a medium reservoir. Because the culture vessel has a constant volume, every time a drop of medium is added to the culture vessel, one drop of cell containing material leaves the vessel. The dilution rate of the vessel $(D)$ is computed by dividing the flow rate of medium leaving the reservoir $(F)$ by the volume of the culture vessel $(V)$ and has the units of $\mathrm{h}^{-1}$. At steady state, some nutrient must be limiting, and the rate of cell production $(\mu x)$ must be equal to the rate of cell loss through overflow (Dx). If $\mu x=D x$, the growth rate, $\mu$, must be equal to the dilution rate, $D$.

Maintenance can be estimated from growth rate-dependent declines in yield (growth efficiency). In the derivation of Marr [1962], maintenance (a) is expressed as an absolute rate $\left(\mathrm{h}^{-1}\right)$, and Marr assumed that bacteria would grow even faster if they did not have this non-growth function. Three years later, Pirt [1965] expressed maintenance as a specific rate (mmol ATP or glucose per mg cells per $\mathrm{h}$ ), but the 2 approaches are interrelated: $\mathrm{a}=\mathrm{m} /$ $Y_{G}$ where $Y_{G}$ is the yield if there were no maintenance (theoretical maximum yield). The inclusion of maintenance energy in bacterial energetics helped to explain why bacteria did not achieve the theoretical value proposed by Stouthamer [1973], but it could not begin to explain the discrepancy of rapidly growing cells that would be expending relatively little of their overall energy on maintenance.

The concept of maintenance and its impact on yield became even more complicated when Tempest and his colleagues conducted continuous culture studies where nutrients other than energy (glucose) limited growth [Teixeira De Mattos et al., 1983; Neijssel and Tempest, 1976; Tempest, 1978; Tempest and Neijssel, 1978; Streekstra et al., 1987]. If continuous cultures were ammonia-, sulfate-, potassium or phosphate-limited, the 'apparent' maintenance value was as much as 10 -fold greater. But why would it take less energy to maintain a glucose-limited cell? By the 1980s, it became apparent that many bacteria used another avenue of energy dissipation (energy spilling) that was distinct from maintenance [Russell and Cook, 1995] (fig. 1).

\section{Is There a Biochemical Mechanism?}

Westerhoff et al. [1982, 1983] likewise noted that 'thermodynamic efficiency of microbial growth is low', and they concluded this lack of efficiency must be needed for 'maximal growth rate'. In a more recent review, Von Stockar and Liu [1999] re-explored the relationships of growth, entropy and enthalpy, and stated that 'heat generation can rid microorganisms of internal entropy production resulting from maintenance and growth processes'. However, neither of these thermodynamic approaches detailed a specific biochemical mechanism. In the 1980s, Otto [1984] noted that certain sequences of catab- 
olism can also serve as anabolic pathways (e.g. glycolysis and gluconeogenesis) and proposed that individual steps might act in an antagonistic fashion (e.g. phosphofructokinase and fructose 1,6-diphosphatase, glycogen synthetase and glycogen glycogenolysis, glucokinase or glucose PTS and glucose-6-phosphatase). However, direct evidence of futile enzyme cycles was not provided, and it has now become apparent that such enzymes are tightly regulated (e.g. allosteric effectors like phosphoenolpyruvate, fructose-6-phosphate, FDP, ADP, AMP), so ATP will not be wasted [Cook and Russell, 1995].

Studies with $E$. coli have given us insights into a great many aspects of bacterial metabolism, but it is not a good model for studying energy spilling. E. coli can store large amounts of glucose as glycogen. It is not easily de-energized, and often uses pathways of catabolism (e.g. respiration) that do not have clearly defined stoichiometries of ATP production. Because the cell membrane is protected by an outer-membrane, intracellular volume is difficult to estimate, and potentially useful tools such as ionophores cannot be used on intact cells. To circumvent these latter problems, we selected Streptococcus bovis, a Gram-positive species that only uses substrate level phosphorylation and never stores glycogen or other energy sources. Because glucose is transported by the phosphotransferase system [Russell, 1990], and lactic acid bacteria can reserve a pool of phosphoenolpyruvate [Thompson, 1978], glucose fermentation can be re-initiated very quickly, even after a significant period of starvation.

Most studies of bacterial energetics were simple exercises of 'feeding and weighing' bacteria, and it was not always clear if the energy source was being used strictly for ATP generation or if it was also being used to synthesize cell material [Stouthamer, 1979]. Microcalorimetry offered a more direct method of estimating the ultimate end-product of energy spilling, namely heat. The first study with $S$. bovis established several important characteristics of energy spilling [Russell and Strobel, 1990]. First, non-growing resting cell suspensions that were either limited by nitrogen or treated with the protein synthesis inhibitor, chloramphenicol, consumed glucose and produced heat 10 -fold faster than the maintenance coefficient of glucose-limited continuous cultures. Secondly, the rate of energy spilling could be enhanced by ionophores and protonophores that dissipated ion gradients across the cell membrane. Thirdly, energy spilling was abolished by DCCD (dicyclohexylcarbodiimide), an inhibitor of the $\mathrm{F}_{1} \mathrm{~F}_{\mathrm{O}}$ ATPase. Given these observations, it became apparent that the energy spilling mechanism of
S. bovis was mediated by membrane ATPase activity and a futile cycle of protons through the cell membrane. Direct comparisons of heat $(\mu \mathrm{W})$ with ATP production directly and measurements of membrane voltage provided a means of using Ohm's law to estimate changes in membrane resistance (proton influx) [Russell, 1992a].

\section{How Is the Energy Spilling of S. bovis Regulated?}

Growth studies indicated that energy spilling was not just a characteristic of 'resting cells'. Glucose-limited continuous cultures did not spill energy, but rapidly growing cells spilled as much as $25 \%$ of their ATP [Russell, 1991b]. The question then became, how was energy spilling being regulated? In bacteria and other living cells, the ratio of ATP to ADP changes little until the cells are starved and dying. E. coli uses cAMP as a signal to regulate the transcription of certain proteins (most notably lactose permease), but there is little evidence that this signal is important in non-enteric bacteria. In low $\mathrm{G}+\mathrm{C}$ Gram-positive bacteria (including $S$. bovis), the glycolytic intermediate fructose 1,6 bis-phosphate (FDP) can vary as much as 40 -fold depending on the glycolytic rate [Thompson, 1978; Bond and Russell, 1996], and FDP can act as a regulator of lactate production [Wolin, 1964], inducer expulsion [Cook et al., 1995] and transcription [Reizer et al., 1998].

Studies with permeabilized $S$. bovis cells indicated that FDP could play a role in energy spilling by improving the affinity of the $\mathrm{F}_{1} \mathrm{~F}_{\mathrm{O}}$-ATPase for ATP by as much as 5 -fold [Bond and Russell, 1996]. However, later work indicated that the role of FDP in energy spilling was primarily mediated by its effect on intracellular inorganic phosphate $\left(\mathrm{P}_{\mathrm{i}}\right)$ [Bond and Russell, 1998]. When FDP increased, $\mathrm{P}_{\mathrm{i}}$ decreased, and this change in $P_{i}$ increased the $\Delta \mathrm{lG}$ of ATP hydrolysis $(\Delta \mathrm{G}$ p of ATP $=-285 \mathrm{mV}-62 \log ([\mathrm{ATP}] /$ $\left.[\mathrm{ADP}] \times\left[\mathrm{P}_{\mathrm{i}}\right]\right)$ from -410 to $-450 \mathrm{mV}$ (fig. 2). This increase in driving force available to the ATPase was consistent with an increase in $\Delta \mathrm{p}(-80$ to $-140 \mathrm{mV})$. The relationship between $\Delta \mathrm{p}$ and the rate of energy spilling was clearly non-ohmic, and the 'leak' of protons through the cell membrane seemed to have a threshold of approximately $-80 \mathrm{mV}$ [Bond and Russell, 2000].

It has long been recognized that amino acid sources often stimulate the growth yield of S. bovis [Russell, 1993] and other bacteria, but the calculations of Stouthamer [1973] indicate that it costs nearly as much ATP to take up an amino acid as it would to synthesize one de novo. The provision of amino acids as an exogenous carbon source would spare some carbon so more of the energy source could actually be devoted to ATP production, but 


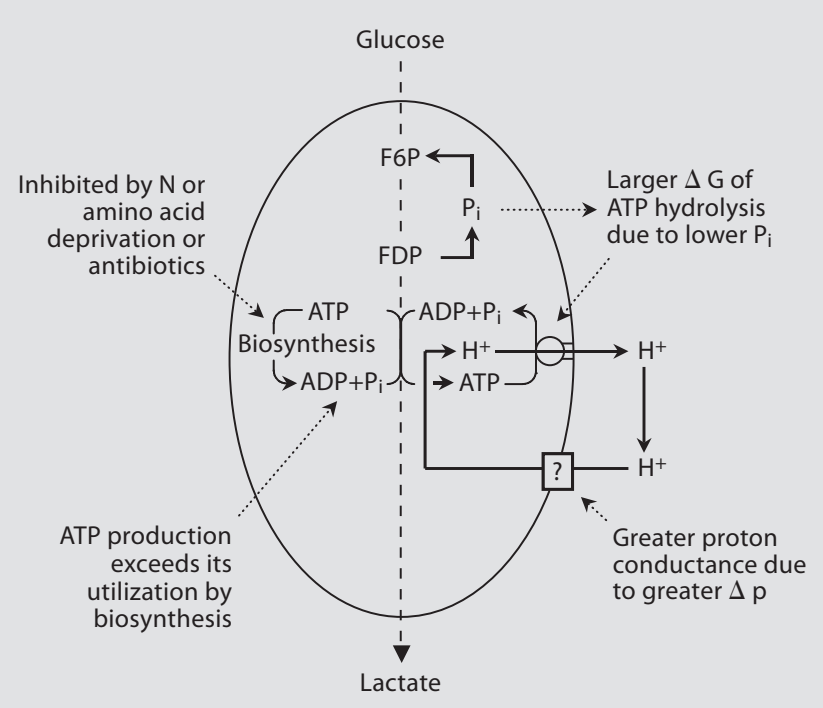

Fig. 2. The proposed mechanism of energy spilling in $S$. bovis. FDP $=$ Fructose 1.6bis-phosphate; F6P = fructose- 6 -phosphate; $\mathrm{P}_{\mathrm{i}}=$ inorganic phosphate; $\Delta \mathrm{p}=$ protonmotive force.

even this effect could not explain the relationship between amino acids and cell yield [Russell, 1993]. The effect of amino acids on yield appears to be mediated via energy spilling. When bacteria have amino acids, they typically grow faster (as much as twice as fast), and the balance of anabolic and catabolic rates are more closely matched [Russell and Cook, 1995].

The idea that amino acids could decrease energy spilling was demonstrated with rapidly growing continuous cultures of S. bovis [Bond and Russell, 1998]. S. bovis is an unusual lactic acid bacterium, and it can use ammonia as a sole nitrogen source for growth [Wolin et al., 1959]. When $S$. bovis had only ammonia as a nitrogen source, intracellular FDP was high $(>10 \mathrm{mM}), \mathrm{P}_{\mathrm{i}}$ was low $(<12$ $\mathrm{mM}$ ), the $\Delta \mathrm{G}$ of ATP hydrolysis was $-455 \mathrm{mV}$, the $\Delta \mathrm{p}$ was $-120 \mathrm{mV}$ and the ATP yield was only $7 \mathrm{~g}$ cell protein per mole of ATP generated. The addition of an amino acid source to the medium reservoir completely changed the energetics. FDP decreased ( $5 \mathrm{mM}), \mathrm{P}_{\mathrm{i}}$ increased (32 mM), and $\Delta \mathrm{G}$ and $\Delta \mathrm{p}(-80 \mathrm{mV})$ declined. The decrease in $\Delta \mathrm{p}-$ dependent energy spilling results in a nearly 2 -fold increase in growth efficiency.

By comparing the $\Delta \mathrm{p}$ with $\Delta \mathrm{G}$ of ATP hydrolysis, it became possible to estimate the $\mathrm{H}^{+}$to ATP stoichiometry [Bond and Russell, 1998], and use standard electrical equations $($ watts $=$ amperage $\times$ voltage; amperage $=1 /$ re- sistance $\times$ voltage) to estimate the resistance of the cell membrane to $\mathrm{H}^{+}$. At very slow rates of energy spilling, the apparent stoichiometry of $\mathrm{H}^{+}$to ATP was greater than 4 to 1 , but the value stabilized at approximately a value of 3.3 when the rates of energy spilling increased. The decrease in apparent $\mathrm{H}^{+} / \mathrm{ATP}$ indicates that the reaction was closer to equilibrium when the cells were spilling energy more slowly. However, when the $\Delta \mathrm{G}$ went up, $\Delta \mathrm{p}$ did not go up as much, and the reaction proceeded at a faster rate (proportionally more 'push' on the ATP hydrolysis side). This effect shows how the leak helps to accelerate the ATPase, but it would not affect the conductance measurements per se.

Even 'acid-tolerant' lactic acid bacteria tend to grow less efficiency at acidic $\mathrm{pH}$, and this effect was traditionally explained by the ability of fermentation acids to move freely across the cell membrane, dissociate in the more alkaline interior and cause uncoupling [Jay, 1989]. The uncoupling theory of fermentation acid toxicity, however, did not explain why some bacteria were much more sensitive than others, and the ability of fermentation acids to act as true uncouplers was contradicted by the observation that the anions were not membrane permeable. Experiments with $S$. bovis indicated that it could let its intracellular $\mathrm{pH}$ decline significantly and that this decline prevented large and potentially toxic accumulation of fermentation acid anions [Russell, 1991a]. This ability to let intracellular $\mathrm{pH}$ decline appears to be a generalized strategy of bacteria that grow well in the presence of fermentation acids even when the $\mathrm{pH}$ is acidic [Russell and Diez Gonzalez, 1998].

Continuous culture studies indicated that $S$. bovis did indeed grow more inefficiently when fermentation acids were present and the $\mathrm{pH}$ was acidic [Russell and Dombrowski, 1980], but this effect can be explained by energy spilling. When intracellular $\mathrm{pH}$ declines to prevent toxic accumulation of fermentation acid anions [Russell, 1991a], the glycolytic rate decreased, but the effect on anabolism was even greater [Russell, 1992]. Another feature that energy spilling explained was lag phase. Laboratory cultures that are inoculated in fresh medium often 'lag' before growth is observed. One reason for lag time is viability. If the inoculum has a large number of dead cells, these cells must be diluted out by growth before net growth is observed. Lag is avoided by using 'fresh' cultures that have a high number of viable cells, but experiments with $S$. bo$v i s$ indicated that even fresh cultures lagged if they had been grown with ammonia as the nitrogen source [Russell, 1993b]. Because S. bovis cultures that were lagging produced heat at a rapid rate, it appears that they too were 
spilling energy while they were synthesizing a pool of amino acids that could later drive growth.

\section{Why Does the Membrane Resistance of S. bovis}

\section{Decrease?}

Because conventional attempts at mutagenesis did not result in a $S$. bovis mutant that could not spill energy, the pathway of $\mathrm{H}^{+}$across the cell membrane is still a matter of speculation (fig. 2). Brown adipose and a variety of other tissues that produce additional heat (e.g. plant seedlings) have an uncoupling protein called thermogenin (UCP), but this integral mitochondrial membrane protein does not seem to be regulated by changes in membrane voltage as it is in S. bovis. The impact of this protein seems to be regulated by the amount of protein present rather than a change in activity of protein that has already been synthesized. For example, the amount of UCP transcript in mitochondria of shoots and roots of maize seedlings doubled after salt stress [Dlaskova et al. 2006]. In $S$. bovis, a large increase in energy spilling occurred almost immediately after growth was inhibited with chloramphenicol, and this results indicated that proton conductance was being regulated directly not just via protein synthesis [Russell and Strobel, 1990]. An interesting, but still unproven, hypothesis is that the membrane conductance of $S$. bovis cells to $\mathrm{H}^{+}$is mediated by a variety of proteins that serve as normal carriers. If $\mathrm{H}^{+} /$symporters simply translocated only $\mathrm{H}^{+}$or more $\mathrm{H}^{+}$per substrate when the membrane voltage was high, the same effect could be elicited.

\section{What Happens if Bacteria Do Not Spill Energy?}

The rumen is typically a energy-limited system, and simple growth experiments indicated that the ruminal bacterium Prevotella bryantii (formerly Bacteroides ruminicola) $\mathrm{B}_{1} 4$ could not survive in continuous culture if nitrogen was limiting and glucose was in excess [Russell, 1992b]. Later work showed that the 'glucose toxicity' was due to methylglyoxal [Russell, 1993a]. When ATP could not be used to grow and synthesize protein, there was insufficient ADP to fuel glycolysis, and the fermentation shifted to the methylglyoxal shunt, a pathway that does not generate ATP or require ADP [Russell, 1993]. E. coli has an enzyme (glyoxalase) that can convert the highly reactive methylglyoxal to $\mathrm{D}$-lactate, but it too can suffer from methylglyoxal toxicity if nitrogen, and in particular amino nitrogen, is limiting [Cooper and Anderson, 1970; Ferguson et al., 1998]. Methylglyoxal has been detected in ruminal fluid, but its impact on ruminal ecology has not been addressed [Lodge-Ivey et al., 2004].

Energy Spilling
Another ruminal bacterium that does not spill energy and can be killed by excess carbohydrate is Fibrobacter succinogenes [Maglione and Russell, 1997], but this toxicity cannot be explained by methylglyoxal. Nitrogen-limited, cellobiose-excess cultures had little ATP and a very low $\Delta \mathrm{p}$ and cell viability. Methylglyoxal could not be detected in the extracellular culture fluid, and $F$. succinogenes was more resistant to methylglyoxal than either $P$. bryantii or E. coli [Maglione and Russell, 1997]. The only parameter that could be correlated with the toxicity was intracellular glycogen. The nitrogen-limited, glucose-excess cultures had more than twice as much intracellular glycogen as protein. The carbohydrate-toxicity of F. succinogenes is probably a laboratory artifact. The niche of F. succinogenes in the rumen is cellulose digestion, and 'excess-cellulose' did not cause a decrease in viability [Thomas and Russell, 2003]. The inability of cellulose to be as toxic as cellobiose can in turn be explained by the observation that the cellulases of $F$. succinogenes seems to be unusually sensitive to feedback inhibition by cellobiose [Maglione et al., 1997].

\section{Do Other Bacteria Spill Energy?}

As mentioned earlier, bacteria that store glycogen and use pathways other than substrate level phosphorylation to synthesize ATP do not make good bioenergetic models, but here is some evidence suggesting that enteric bacteria may also use futile ion cycles to spill energy. In $E$. coli, intracellular potassium is a prime factor regulating turgor pressure, and this bacterium has multiple transport systems for potassium uptake as well as efflux. Mulder et al. [1986] studied the impact of potassium transport systems on the growth efficiency of $E$. coli when potassium was limiting. Because a mutant which was defective in high-affinity potassium transport utilized glucose more efficiently [Buurman et al., 1991], it appeared that the wild type was taking up potassium by the highaffinity, ATP-driven (Kdp) system and losing potassium on the low-affinity, proton symport (Trk) system. Because the energy spilling of $S$. bovis was neither potassium nor sodium-dependent, the energy spilling reaction of $S$. bovis could not be explained by a similar mechanism [Bond and Russell, 2000].

In the 1970s, Harold and Van Brunt [1977] demonstrated that gramicidin-treated Enterococcus (Streptococcus) faecalis cultures could grow even though they did not have a $\Delta \mathrm{p}$, but it should be noted that the medium was very rich. Because the medium was rich, $\Delta \mathrm{p}$ was not required to drive transport. More recent results indicated that the amino acid fermenting bacterium, Clostridium

J Mol Microbiol Biotechnol 2007;13:1-11 
sporogenes, did not have a significant $\Delta \mathrm{p}$ while it was growing, but a relatively normal $\Delta \mathrm{p}$ was generated if growth was inhibited by either acidic $\mathrm{pH}$ or inhibitors of protein synthesis [Flythe and Russell, 2005]. Because amino acid catabolism continued at a very rapid rate, even in the complete absence of growth, and $\Delta \mathrm{p}$ was only generated if growth was inhibited, it appeared that $\Delta \mathrm{p}$ generation and potassium flux was a mechanism of energy spilling [Flythe and Russell, 2006].

Probably the strongest argument that energy spilling is a common feature of bacteria is derived from growth experiments with the methanogen [Schönheit et al., 1980]. Methanogens are thought to be among the most energy starved bacteria (now archaea) in all of nature, and until the 1980s, the mechanism of ATP generation was not known [Blaut et al., 1990]. Many of the details are now known, and it appears that methanogens derive all of their ATP from chemiosmotic mechanisms. The idea that even methanogens may have evolved energy spilling reactions can be argued from simple growt hexperiments. In nature, hydrogen a common precursor is present at very low concentrations, and the growth yield of methanogens under such conditions is relatively high. However, if methanogens are grown in the laboratory under a high pressure of hydrogen, the growth yield is much lower, and methane is even produced after growth ceases because some other factor has become limiting. 'These findings indicate that methane formation and growth are less tightly coupled at high concentrations of $\mathrm{H}_{2}$ or $\mathrm{CO}_{2}$ in the medium than at low concentrations' [Schönheit et al., 1980]. Liu et al. [2001] used a microcalorimeter to study the acetotrophic methanogen, Methanosarcina barkeri, and concluded that microbial growth was characterized by 'enthalpy increase and correspondingly by a large increase in entropy may be called enthalpy-retarded growth'.

\section{Beneficial or Detrimental?}

In many situations, energy spilling can be viewed as a detrimental process that decreases cell production and the products associated with cells. For instance in ruminant animals (e.g. cattle, sheep, goats, deer, etc.) microbial protein is the primary amino acid source entering the small intestine [Hungate, 1966], and it has long been recognized that the flow of microbial protein from the rumen can be enhanced if the bacteria have amino nitrogen rather than just ammonia. This improvement in the growth yields of rumen bacteria has been explained by a decrease in energy spilling [Van Kessel and Russell, 1996]. Similar cases could be made of biotechnological process- es that seek to produce enzymes, peptide hormones or other valuable cell components. However, in some cases the metabolic end-product of energy spilling itself can be a valuable product. Such is the case in ethanol and solvent production. In both cases, large amounts of product are not produced until growth has ceased [Russell and DiezGonzalez, 1998; Cot et al., 2001].

\section{Basal Metabolic Rate of Mammals}

It has long been recognized that small mammals (rats and mice) have a higher basal metabolic rate than large mammals (cattle, elephants and man). Kleiber [1976] noted that a graph of basal metabolic rate versus body weight could only be made linear if the body weight was expressed as the $3 / 4$ power. However, the reason for this difference was not clear until Brand et al. [1994] examined the mitochondrial proton leak of various animals. Their results indicated that this leak could account for as much as $26 \%$ of the oxygen consumption of animals. Because the leak was significantly greater in smaller animals (greater heat production and substrate consumption rate from each mitochondrion), the greater basal metabolic rate of small animals as compared to larger ones could be explained.

\section{Cancer Cells and Human Disease}

In his last public lecture at Lindau, Germany, Otto Warburg [1966] drew analogies between human cancer cells and lactic acid bacteria. One of the similarities was very rapid rates of glucose catabolism and 'uncoupled growth' that we have discussed as 'energy spilling'. Ephraim Racker, the scientist that uncovered the mechanism of substrate phosphorylation, isolated purified and reconstituted the $\mathrm{F}_{1} \mathrm{~F}_{\mathrm{O}}$ ATPase, and provided the final proof for Peter Mitchell's chemiosmotic theory, was taken with Warburg's comments, and in the late 1970s directed a graduate student, Mark Spector, to pursue this idea.

Spector's experiments appeared to go very well and a paper was published [Spector et al., 1981]. 'Recent work has identified a cascade of membrane-bound protein kinases in Ehrlich ascites tumor cells. One result of activation of the cascade is the phosphorylation of the $\beta$-subunit of the $\mathrm{Na}^{+} \mathrm{K}^{+}$-ATPase, which causes inefficient $\mathrm{Na}^{+}$ pumping and is at least in part responsible for the high aerobic glycolysis of Ehrlich ascites tumor cells.' To honor Warburg, Racker called this cascade of phosphoryla- 
tion and high glycolytic rate, the 'Warburg effect' [Racker and Spector, 1981]. However, it later became evident that some of Spector's key experiments could not be repeated and appeared to be falsified [Racker, 1989]. Nonetheless, the 'Warburg effect' has once again gained respectability and interest. 'Two prominent cancer biologists contend that a shift in energy production from oxidative phosphorylation to glycolysis - the so-called "Warburg effect" - is a fundamental property of cancer cells, not just a byproduct of the cell's transformation into cancer. "We think it's a requirement of transformation", said University of Pennsylvania cancer biologist Craig Thompson, MD. "You can't become fully transformed until you've had this shift." If Thompson is right, the implication is enormous: a whole new area of vulnerability for cancer cells, one that promises novel targeted treatments' [Garber, 2004]. 'Uncoupling or slippage' via Ptype cation ATPases creates heat in the uncoupled state, and this property is now thought to be involved in a number of diseases including ageing, ischemia and cardiac failure [Berman, 2001].

\section{Conclusions}

The idea that organisms always utilize energy (ATP) in an efficient manner is contradicted by the observation that many bacteria and eukaryotes appear to have energy spilling reactions. In at least some cases, these reactions appear to involve a futile cycle of ions through the cell membrane.

\section{Acknowledgments}

My research was supported by the US Dairy Forage Research Center, Madison, Wisc., USA. The author would like to thank Drs. Gregory Cook, Daniel Bond and Michael Flythe for their efforts to delineate mechanisms of energy spilling and their constructive comments in preparing the manuscript.

\section{References}

- Bauchop T, Elsden SR: The growth of microorganisms in relation to their energy supply. J Gen Microbiol 1960;23:457-469.

-Berman MC: Slippage and uncoupling in P-type cation pumps: implications for energy transduction mechanisms and regulation of metabolism. Biochim Biophys Acta 2001;1503 329-340.

Blaut M, Muller V, Gottschalk G: Energetics of Methanogens; in Krulwich T (ed): Bacterial Energetics. New York, Academic Press, 1990, pp 505-537.

Bond DR, Russell JB: A role for fructose 1,6-diphosphate in the ATPase-mediated energyspilling reaction of Streptococcus bovis. Appl Environ Microbiol 1996;62:2095-2099.

Bond DR, Russell JB: Relationship between intracellular phosphate, proton motive force, and the rate of non-growth energy dissipation (energy spilling) in Streptococcus bovis JB1. Appl Environ Microbiol 1998;64:976981.

Bond DR, Russell JB: Proton motive force regulates the membrane conductance of Streptococcus bovis in a non-ohmic fashion. Microbiology 2000;146:687-694.

-Brand MD, Chien L-F, Ainscow EK, Rolfe DFS, Porter RK: The causes and functions of mitochondrial proton leak. Biochim Biophys Acta 1994;1187:132-139.
Brock TD, Madigan JL: Biology of Microorganisms, ed 6, p 112. Englewood Cliffs, Prentice Hall, 1991.

- Buurman ET, Teixeira De Mattos MJ, Neijssel OM: Futile cycling of ammonium ions via the high affinity potassium uptake system (Kdp) of Escherichia coli. Arch Microbiol 1991;155:391-395.

Buurman ET, Pennock J, Tempest DW, Teixeira De Mattos MJ, Neijssel OM: Replacement of potassium ions by ammonium ions in different micro-organisms grown in potassiumlimited chemostat culture. Arch Microbiol 1989;152:58-63.

Cook GM, Ye JJ, Russell JB, Saier MH: Properties of two sugar phosphate phosphatases from Streptococcus bovis and their involvement in inducer explusion. J Bacteriol 1995;177: 7007-7009.

Cooper RA, Anderson A: The formation and catabolism of methylglyoxal during glycolysis in Escherichia coli. FEBS Lett 1970;11:273276.

Cooper S: The origins and meaning of the Schaechter-Maaloe-Kjeldgaard experiments. J Gen Microbiol 1993;139:11171124.

Cot M, Loret MO, Francois J, Benbadis L: Physiological behaviour of Saccharomyces cerevisiae in aerated fed-batch fermentation for high level production of bioethanol. Biotechnol Bioeng 2001;75:345-354.
Dimroth P: Sodium ion transport decarboxylases and otheraspects of sodium cycling in bacteria. Microbiol Rev 1987;51:320-340.

-Dlaskova A, Spacek T, Skobisova E, Santorova J, Jezek P: Certain aspects of uncoupling due to mitochondrial uncoupling proteins in vitro and in vivo. Biochim Biophys Acta 2006; 1757:467-473.

Feniouk BA, Mulkidjanian AY, Junge W: Proton slip in the ATP synthase of Rhodobacter capsulatus: induction, proton conduction, and nucleotide dependence. Biochim Biophys Acta $2005 ; 1706: 1184-1194$

-Ferguson GPT, Totemeyer S, MacLean MJ, Booth IR: Methylglyoxal production in bacteria: Suicide or survival? Arch Microbiol 1998; 170:209-218.

Fillingame RH, Dmitriev OY: Structural model of the transmembrane $\mathrm{F}_{\mathrm{o}}$ rotary sector of $\mathrm{H}+$-transporting ATP synthase derived by solution NMR and intersubunit cross-linking in situ. Biochim Biophys Acta 2002;1565: 232-245.

Flythe MD, Russell JB: The ability of acidic $\mathrm{pH}$, growth inhibitors and glucose to increase the protonmotive force and energy spilling of amino acid fermenting Clostridium sporogenes MD1 cultures. Arch Microbiol 2005; 183:236-242. 
Flythe MD, Russell JB: Fermentation acids inhibit amino acid deamination by Clostridium sporogenes $\mathrm{MD} 1$ via a mechanism involving a decline in intracellular glutamate rather than protonmotive force. Microbiology 2006;152:2619-2624.

Flythe MD, Russell JB: The effect of acidic $\mathrm{pH}$ on the ability of Clostridium sporogenes MD1 to take up and retain intracellular potassium. FEMS Lett 2006;267:46-50.

Garber K: News. J Natl Cancer Inst 2004;96: 1805-1806.

Gottschalk G: Bacterial Metabolism, ed 2. New York, Springer, 1986.

Harold FM: The Vital Force: A Study of Bioenergetics. San Francisco, Freeman, 1986.

Harold FM, Van Brunt J: Circulation of $\mathrm{H}^{+}$and $\mathrm{K}^{+}$across the plasma membrane is not obligatory for bacterial growth. Science 1977;197: 372-373.

-Herbert D, Elsworth R, Telling RC: The continuous culture of bacteria: a theoretical and experimental study. J Gen Microbiol 1956;14: 601-622.

- Hinkle PC, Kumar MA, Resetar A, Harris DL: Mechanistic stoichiometry of mitochondrial oxidative phosphorylation. Biochem 1991; 30:3576-3582.

Hungate R.E.: The rumen and its microbes, p. 282. 1966. Academic Press, New York, N.Y.

Jay JM: Modern Food Microbiology, ed 4. New York, Van Nostrand Reinhold, 1989.

Kleiber M: Davis, Memorial Book Department of Animal Science, University of California, 1976. http://animalscience.ucdavis.edu/memorial/kleiber.htm

Klotz IM: Energy Changes in Biochemical Reactions. New York, Academic Press, 1967.

Lehninger AL: Biochemistry, New York, Worth Publishers, 1975, p 12.

Lehninger AL, Nelson DL, Cox MM: Principles of Biochemistry. New York, Worth Publishers, 1993, p 6

Lipmann F: Metabolic generation and utilization of phosphate bond energy. Adv Enzymol 1941;1:99-162.

-Liu JS, Marison IW, Von Stockar U: Microbial growth by a net heat up-take: a calorimetric and thermodynamic study on acetotrophic methanogenesis by Methanosarcina barkeri. Biotechnol Bioeng 2001;275:170-180.

Lodge-Ivey SL, May T, Petersen MK, Strickland JR: Determination of methylglyoxal in ruminal fluid by high-performance liquid chromatography using fluorometric detection. J Agric Food Chem 2004;52:68756878.

Maglione G, Russell JB: The adverse effect of nitrogen limitation and excess-cellobiose on Fibrobacter succinogenes. Appl Microbiol Biotechnol 1997;48:720-725.

-Maglione G, Russell JB, Wilson DB: Kinetics of cellulose digestion by Fibrobacter succinogenes S85. Appl Environ Microbiol 1997;63: 665-669.

Maloney PC: Microbes and membrane biology. FEMS Microbiol Rev 1990;87:91-102.
Marr AG, Nilson EH, J CD: The maintenance requirement of Escherichia coli. Ann NY Acad Sci 1962;102:536-548.

Mitchell P: Coupling of phosphorylation to electron and hydrogen transfer by a chemi-osmotic type of mechanism. Nature 1961;191: 144-148.

Monod J: The growth of bacterial cultures. Ann Rev Microbiol 1949;3:371-394.

Morowitz HJ: Foundations of Bioenergetics. New York, Academic Press, 1978, p 344.

Mulder MM, Teixeira MJ, Postma PW, Van Dam $\mathrm{K}$ : Energetic consequences of multiple $\mathrm{K}^{+} \mathrm{up}-$ take systems in Escherichia coli. Biochim Biophys Acta 1986;851:223-228.

Neijssel OM, Tempest DW: Bioenergetic aspects of aerobic growth of Klebsiella aerogenes NCTC 418 in carbon-limited and carbonsufficient culture. Arch Microbiol 1976;107: 215-221.

Nichols DG: Bioenergetics: An Introduction to Chemiosmotic Theory. New York, Academic Press, 1982.

Novick A, Szilard L: Experiments with the chemostat on spontaneous mutations of bacteria. PNAS 1950;36:708-719.

Otto R: Uncoupling of growth and acid production in Streptococcus cremoris. Arch Microbiol 1984;140:225-230.

Pirt S.J.: The maintenance energy of bacteria in growing cultures. Proc R Soc Lond B Biol Sci 1965;163:224-231.

Racker E: Mechanisms of energy transformations. Annu Rev Biochem 1977;46:10061014.

Racker E: A view of misconduct in science. Nature 1989;339:91-93.

Racker E, Spector M: Warburg effect revisited: merger of biochemistry and molecular biology. Science 1981;213:303-307.

Reizer J, Hoischen C, Titgemeyer F, Rivolta C, Rabus R, Stulke J, Karamata D, Saier MH Jr, Hillen W: A novel protein kinase that controls carbon catabolite repression in bacteria. Mol Microbiol 1998;27:1157-1169.

Repke KRH: Reinstatement of the ATP high energy paradigm. Mol Cell Biochem 2004;160161:95-99.

Russell JB: Heat production by ruminal bacteria in continuous culture and its relationship to maintenance energy. J Bacteriol 1986;168: 694-701.

Russell JB: Low affinity, high capacity system of glucose transport in the ruminal bacterium Streptococus bovis: evidence for a mechanism of facilitated diffusion. Appl Environ Microbiol 1990;56:3304-3307.

Russell JB: Resistance of Streptococcus bovis to acetic acid at low $\mathrm{pH}$ : relationship between intracellular $\mathrm{pH}$ and anion accumulation. Appl Environ Microbiol 1991a;57:255-259.

Russell JB: A re-assessment of bacterial growth efficiency: the heat production and membrane potential of Streptococcus bovis in batch and continuous culture. Arch Microbiol 1991b;155:559-565.
Russell JB: The effect of $\mathrm{pH}$ on the heat production and membrane resistance of Streptococcus bovis. Arch Microbiol 1992a;158:54-58.

Russell JB: Glucose toxicity and inability of Bacteroides ruminicola to regulate glucose transport and utilization. Appl Environ Microbiol 1992b;58:2040-2045.

Russell JB: The glucose toxicity of Prevotella ruminicola: methylglyoxal accumulation and its effect of membrane physiology. Appl Environ Microbiol 1993a;59:2844-2850.

Russell JB: Effect of amino acids on the heat production and growth efficiency of Streptococcus bovis: balance of anabolic and catabolic rates. Appl Environ Microbiol 1993b;59: 1747-1751.

Russell JB, Dombrowski DB: Effect of $\mathrm{pH}$ on the efficiency of growth by pure cultures of rumen bacteria in continuous culture. Appl Environ Microbiol 1980;39:604-610.

Russell JB, Strobel HJ: ATPase-dependent energy spilling by the ruminal bacterium, Streptococcus bovis. Arch Microbiol 1990;153: $378-383$.

Russell JB, Cook GM: Energetics of bacterial growth: balance of anabolic and catabolic reactions. Microbiol Rev 1995;59:48-62.

Russell JB, Diez-Gonzalez F: The effects of fermentation acids on bacterial growth. Adv Microbial Physiol 1998;39, 205-234.

Russell JB, Bond DR, Cook GM: The fructose diphosphate/phosphate regulation of carbohydrate metabolism in low G + C Gram-positive anaerobes. Res Microbiol 1996;147: 528-535.

-Schönheit P, Moll J, Thauer RK: Growth parameters (Ks, $\mu \max , \mathrm{Ys}$ ) of Methanobacterium thermoautotrophicum. Arch Microbiol 1980; 127:59-65.

Skulachev VP: The latest news from the sodium world. Biochim Biophys Acta 1994;1187: 216-221.

Spector M, Pepinsky RB, Vogt VM, Racker E: A mouse homolog to the avian sarcoma virus src protein is a member of a protein kinase cascade. Cell 1981;25:9-21.

Stouthamer AH: The search for correlation between theoretical and experimental growth yields; in Quayle JR (ed): International Review of Biochemistry and Microbial Biochemistry. Baltimore, University Park Press, 1979, pp 1-47.

Stouthamer AH: A theoretical study on the amount of ATP required for synthesis of microbial cell material. Ant van Leeuwenhoek 1973;39:545-565.

Stouthamer AH, Bettenhaussen CW: A continuous culture study of an ATPase-negative mutant of Escherichia coli. Arch Microbiol 1977; 113:185-189.

Streekstra H, Buurman ET, Hoitink CWG, Teixeira De Mattos MJ, Neijssel OM, Tempest DW: Fermentation shifts and metabolic reactivity during anaerobic carbon-limited growth of Klebsiella aerogenes NCTC 418 on fructose, gluconate, mannitol and pyruvate. Arch Microbiol 1987;148:137-143. 
Teixeira De Mattos MJ, Tempest DW: Metabolic and energetic aspects of the growth of Klebsiella aerogenes NCTC 418 on glucose in anaerobic chemostat culture. Arch Microbiol 1983;134:80-85.

Tempest DW: The biochemical significance of microbial growth yields: a reassessment. Trends Biochem Sci 1978;3:180-184.

Tempest DW, Neijssel OM: Eco-physiological aspects of microbial growth in aerobic nutrient-limited environments; in Alexander M (ed): Advanced Microbial Ecology. New York, Plenum Press, 1978, pp 105-153.

Thomas S, Russell JB: The effect of cellobiose, glucose and cellulose on the survival of $\mathrm{Fi}$ brobacter succinogenes $\mathrm{A} 3 \mathrm{C}$ cultures grown under ammonia limitation. Curr Microbiol 2003;48:219-223.
Thompson J: In vivo regulation of glycolysis and characterization of sugar: phosphotransferase systems in Streptococcus lactis. J Bacteriol 1978;136:465-476.

-Van Kessel JS, Russell JB: The effect of amino nitrogen on the energetics of ruminal bacteria and its impact on energy spilling. J Dairy Sci 1996;79:1237-1243.

Von Stockar U, Liu JS: Does microbial life always feed on negative entropy? Thermodynamic analysis of microbial growth. Biochim Biophys Acta 1999;1412:191-211.

Warburg O: The prime cause and prevention of disease: Dr. Otto Warburg's address to nobel laureates, June 30, 1966 at Lindau, Lake Constance, Germany, 1966. http://www.ionizers. org/Otto-Warburg.html.
-Westerhoff HV, Hellingwerf KJ, Van Dam K: Thermodynamic efficiency of microbial growth is low but optimal for maximal growth rate. Proc Natl Acad Sci USA 1983; 80:305-309.

Westerhoff HV, Lolkema JS, Otto R, Hellingwerf KJ: Thermodynamics of growth: Non-equilibrium thermodynamics of bacterial growth: the phenomenological and the mosaic approach. Biochim. Biophys. Acta 1982; 683:181-220.

-Wolin MJ, Manning GB, Nelson WO: Ammonia salts as a sole source of nitrogen for the growth of Streptococcus bovis. J Bacteriol 1959;78:147-149.

Wolin MJ: Fructose-1,6-diphosphate requirement of streptococcal lactic dehydrogenases. Science 1964;146:775-777. 